\title{
LASER $\mu$-RAMAN INVESTIGATION OF GREEK BAUXITES FROM THE PARNASSOS-GHIONA ACTIVE MINING AREA
}

\author{
Gamaletsos P. ${ }^{1}$, Godelitsas A. ${ }^{1}$, Chatzitheodoridis E. ${ }^{2}$, and Kostopoulos D. ${ }^{1}$ \\ ${ }^{I}$ National and Kapodistrian University of Athens, Faculty of Geology and Geoenvironment, \\ platon_gk@geol.uoa.gr,agodel@geol.uoa.gr,dikostop@geol.uoa.gr \\ ${ }^{2}$ National Technical University of Athens, School of Mining and Metallurgical Engineering, \\ eliasch@central.ntua.gr
}

\begin{abstract}
Bauxite samples collected with permission from currently active mining areas in the Parnassos-Ghiona Mts district were studied using both conventional (optical microscopy and powder XRD) and, for the first time in the literature, micro-scale advanced non-destructive spectroscopic techniques, in particular Laser $\mu$-Raman. The results showed that the different bauxite types (diasporic or boehmitic) can easily be identified regardless of sample type (porous white-grey or massive redbrown) by recording spectra in the low-wavenumber region $\left(250 \mathrm{~cm}^{-1}-600 \mathrm{~cm}^{-1}\right)$ where distinct bands of the natural AlOOH polymorphs are easily discernible (448 $\mathrm{cm}^{-1}$ for diaspore and $362 \mathrm{~cm}^{-1}$ for boehmite). The method described herein could equally be applied in the laboratory as well as in-situ at the mines for quick and accurate phase determination, in order to bypass the laborious and time-consuming indirect bulk techniques (such as XRD) routinely used to this date.
\end{abstract}

Key words: Raman, Diaspore, Boehmite, Bauxite, Greece.

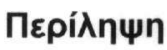

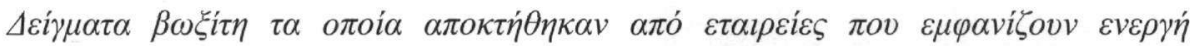

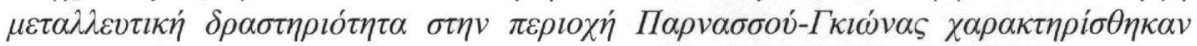

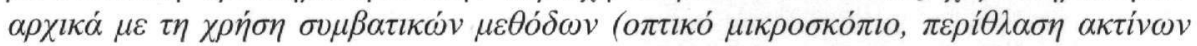

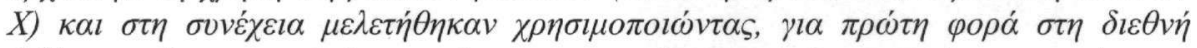

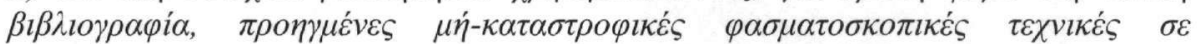

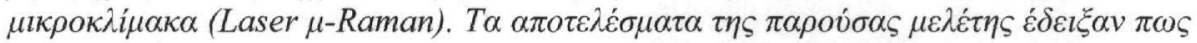

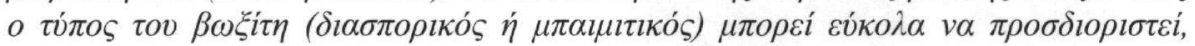

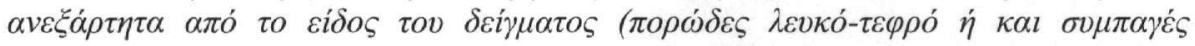

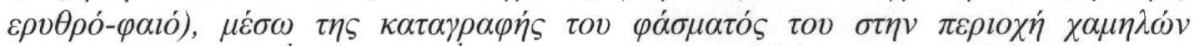

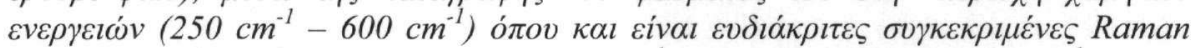

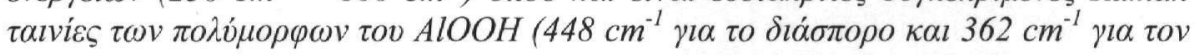

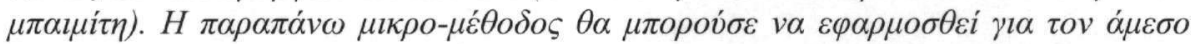

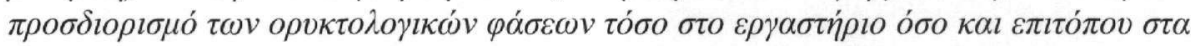

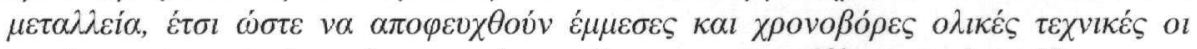

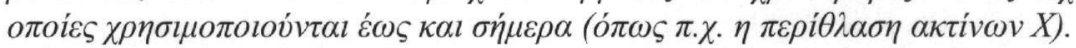

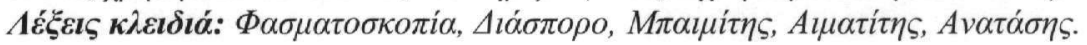




\section{Introduction}

In 2005 , Greece was the twelfth bauxite producer in the world with a total production of $2.2 \times 10^{6}$ tonnes (USGS - Mineral Commodity Summaries, January 2006). The bauxite reserves in Greece are estimated to be $600 \times 10^{6}$ tonnes. It is now established that the Greek mining industry controls the most significant bauxite reserves in the EU (USGS - 2005 Minerals Yearbook). The overall production is mainly related to exploitation of bauxite deposits situated within the ParnassosGhiona geotectonic zone (central Greece) by three mining companies (Aluminium de Grèce S.A., S\&B Industrial Minerals S.A., Elmin S.A.). Almost $72 \%$ of the current Greek aluminium market is covered by domestic production (USGS - 2005 Minerals Yearbook). Most of the raw material is processed by Aluminium de Grèce at its metallurgical plant at Antikyra, Corinthiakos gulf, for the production of alumina and metallic aluminium to be used in industry and constructions. The remainder of the raw bauxite and associated metallurgical products are exported generating an annual income of $\sim 25$ and $\sim 165$ million $€$ respectively, according to Greek Mining Enterprises Association.

Numerous geological studies have been published about the Parnassos-Ghiona allochthonous karst-type bauxite deposits (Aronis 1955, Papastamatiou 1960, Papastamatiou 1964, Bárdossy and Mack 1967, Nia 1971, Valeton, 1972, Maksimović and Papastamatiou 1973, Papastavrou 1974, Mack and Petrascheck 1978, Nicolas and Bildgen 1979, Combes et al. 1981, Bárdossy 1982, Biermann 1983, Combes and Andreou 1983, Arp 1985, Papastavrou 1986, Valeton et al. 1987, Petrascheck 1989, Valeton 1991, Vgenopoulos and Daskalakis 1991, Economopoulos and Vgenopoulos 1998). These ores are hosted within Mesozoic carbonate formations (Fig. 1). The Parnassos-Ghiona geotectonic zone is characterised by nearly continuous sedimentation of epicontinental reef-like carbonates from the Upper Triassic to the Upper Cretaceous (Valeton et al. 1987). In this carbonate sequence three bauxite horizons (from bottom to top: $B_{1}, B_{2}$ and $B_{3}$ ) can be distinguished and they were caused by epirogenic emersion phases and formation of coastal karst reliefs (Valeton et al. 1987, Petrascheck 1989). Horizon $\mathrm{B}_{1}$ is hosted in the calcareous Middle-Upper Jurassic units, horizon $\mathrm{B}_{2}$ in the calcareous Upper/Jurassic - Lower Cretaceous units (Tithonian and Neokomian respectively), whereas horizon $\mathrm{B}_{3}$ is hosted in the calcareous Upper Cretaceous units (Cenomanian - Turonian).

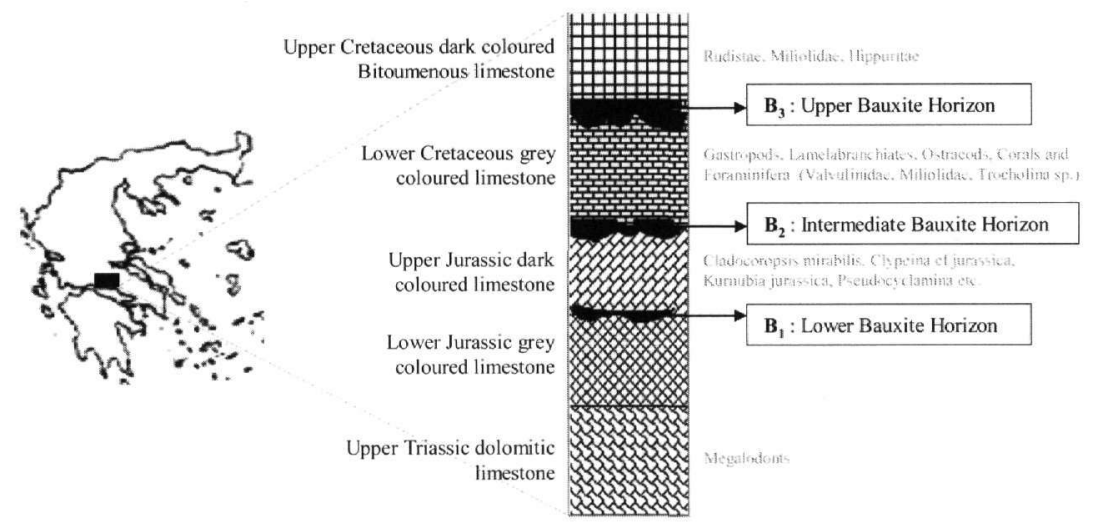

Figure 1 - Stratigraphic position of bauxite horizons $B_{1}, B_{2}$ and $B_{3}$ intercalated with shallowwater Jurassic to Cretaceous limestones of the Parnassos-Ghiona zone (modified, from Valeton et al. 1987)

The main mineralogical and geochemical characteristics of the Parnassos-Ghiona bauxites have been described by several authors using conventional methods such as optical microscopy, SEMEPMA, XRD, XRF, Fire-Assay/AAS/ICP and TGA/DTA (Kiskyras 1960, Nia 1968, Bárdossy and Pantó 1971, Ochsenkühn and Parissakis 1977, Augustithis et al. 1978, Combes 1979, Biermann 1983, Arp 1985, Paspaliaris 1985, Kritsotakis et al. 1986, Papastavrou and Perdikatsis 
1987, Economopoulou-Kyriakopoulou 1991, Laskou 1991, Perdikatsis 1992, OchsenkühnPetropoulou and Ochsenkühn 1995, Laskou 2001, Laskou and Andreou 2003, Laskou 2005, Solymár et al. 2005, Laskou and Economou 2006). More detailed characterization techniques, and particularly TEM and INAA, have also been used (Bárdossy and Mack 1967, Laskou and Economou 1991, Ochsenkühn-Petropoulou and Ochsenkühn 1995, Ochsenkühn et al. 1995, Lymperopoulou 1996, Ochsenkühn et al. 2002). It is evident that the only non-bulk (micro- and nano-scale) instrumental methodology used so far, for the study of Parnassos-Ghiona bauxites, concerns some electron microscopy techniques (TEM and SEM-EPMA). Here, we present, for the first time in the literature, the application of micro-scale, non-destructive, advanced spectroscopic techniques such as laser $\mu$-Raman in the characterisation of typical bauxite samples from the Parnassos-Ghiona active mining area. We demonstrate that this method can equally be applied in the laboratory as well as in-situ at the mines (e.g. by using portable spectrometers) for quick and accurate phase determination, thus bypassing laborious and time-consuming indirect bulk techniques (such as XRD) routinely used to this date.

\section{Materials and Methods}

The investigated bauxite samples were collected during the period March 2006 - September 2006 from mining sites (Fig. 2) of the three Greek companies (Aluminium de Grèce S.A. indicated as "ALM", Elmin S.A. indicated as "ELM" and S\&B Industrial Minerals S.A. indicated as "SAB", Table 1) exploiting bauxite in the Parnassos-Ghiona area (central Greece).
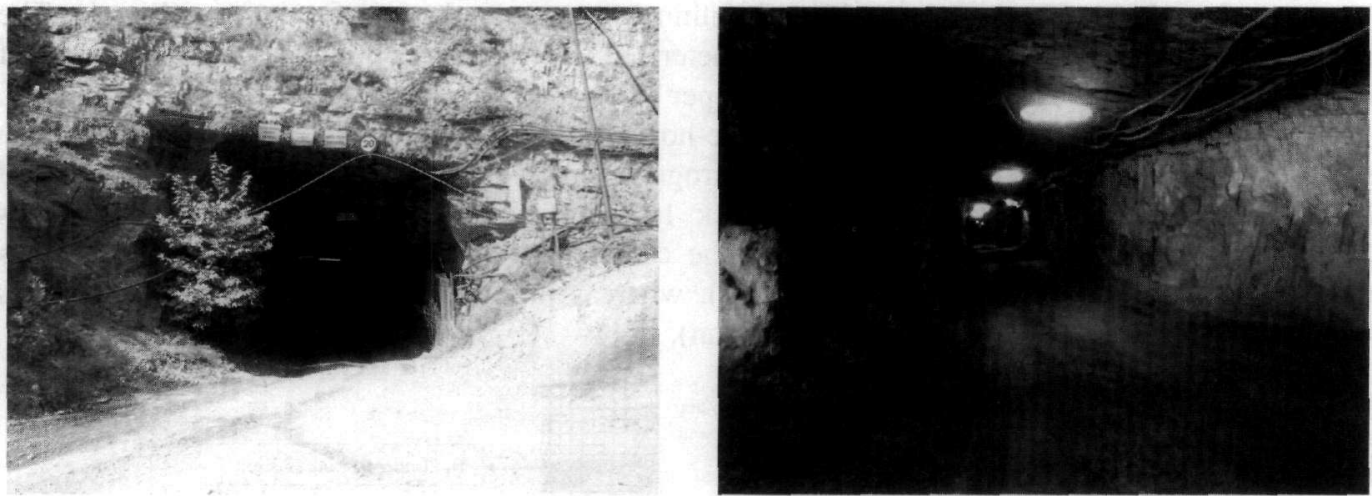

Figure 2 - Bauxite underground works of Aluminium de Grèce at Pera-Lakkos site, Parnassos-Ghiona area

The present investigation is focused on the analysis of bauxite samples from the $2^{\text {nd }}$ (intermediate) and the $3^{\text {rd }}$ (upper) bauxite horizon (Fig. 1, Table 1). All bauxites samples (both white-grey and red-brown) were initially investigated in polished-thin sections using transmitted and reflected light optical microscopy. The mineralogical composition was also examined using powder X-ray diffraction (XRD) on a Siemens D5005 (Bruker AXS) diffractometer using $\mathrm{Cu} K_{\alpha}$-radiation. The Laser $\mu$-Raman spectra were obtained on the polished-thin sections using a Renishaw Ramascope RM 1000 equipment with a HeNe laser at $633 \mathrm{~nm}$, a spectrometer with a grating of 1800 lines $/ \mathrm{mm}$, and a CCD Peltier-cooled detector. The laser beam diameter was adjusted depending on resolution requirements. In any case its maximum energy did not exceed $4 \mathrm{~mW}$.

\section{Results and discussion}

The microscopic and XRD studies have shown that the major mineral phases in the investigated bauxite samples from the Parnassos-Ghiona deposits are the two common AlOOH polymorphs diaspore and boehmite, the typical $\mathrm{Fe}^{\mathrm{III}}$ oxide and oxyhydroxide hematite and goethite, and the $\mathrm{TiO}_{2}$ polymorph anatase. Iron sulphides (such as pyrite) are frequently present. Microscopic 
images (reflected light) of the most common in appearance (red-brown diasporic) bauxite samples are presented in Figure 3. Patches and veins of metallic minerals consisting of iron oxides and sulphides (lighter areas) are included in diasporic matrix (darker areas containing also pisoliths). Most of the characteristic bauxitic pisoliths contain both diaspore and finely dispersed hematite.
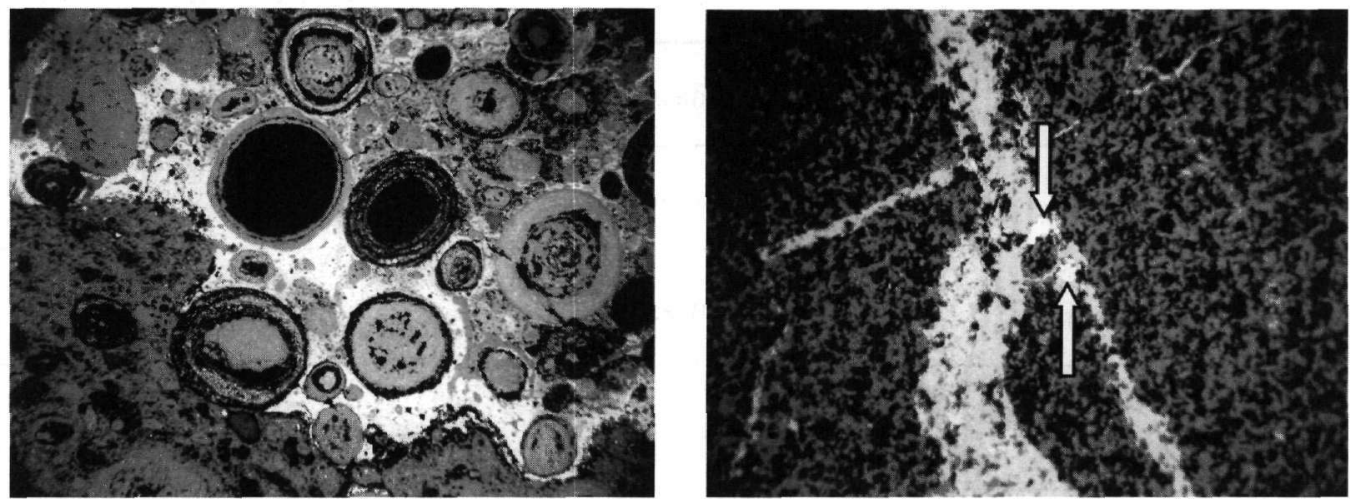

Figure 3 - Representative microscopic images $(\times 100$ and $\times 200)$ from typical red-brown diasporic bauxite samples using reflected light (lighter areas $=\mathrm{Fe}-0 x i d e s$, arrows $=$ sulphides)

Typical XRD patterns of diasporic and boehmitic samples are shown in Figure 4 whereas the complete data are included in Table 1. It should be emphasized that the diasporic bauxite appears both in the form of porous white-grey (high quality) and red-brown samples, while boehmitic bauxite only in the form of massive red-brown samples.
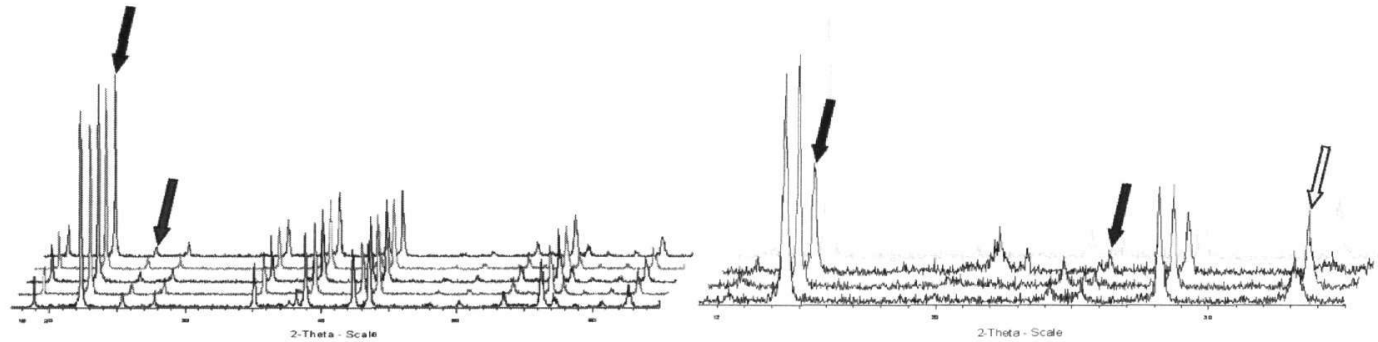

Figure 4 - Powder XRD patterns of white-grey diasporic and red-brown boehmitic bauxite samples. In the first case the diaspore and anatase strongest reflections at $22.26(3.99)$ and 25.35 (3.51) $2 \theta$ ( $d$ in $\AA$ ) are indicated by black and grey arrows respectively, whereas in the second case boehmite, anatase and hematite strongest reflections at $14.48(6.11), 25.35(3.51)$

and 33.27 (2.69) $2 \theta(d$ in $\AA$ ) are indicated by black, grey and white arrows respectively

Conventional chemical methods are not recommended to characterize $\mathrm{AlOOH}$ polymorphs in bauxite samples. Thus powder XRD is fundamentally used in laboratory conditions. However it is rather difficult to use XRD for in-situ measurements in the field and in underground mining areas because portable XRD equipments are not greatly commercialized up to now. Therefore, it is important to suggest convenient spectroscopic methods, such as Laser $\mu$-Raman, which can be easily used for phase determination in any case. The instrument is a bench system capable of confocal imaging with high spectral and spatial resolution. Representative Laser $\mu$-Raman spectra of diasporic bauxite samples investigated during the present study (both white-grey and redbrown), together with standard Raman spectra from the Mineral Spectroscopy Server of CalTech (C) Prof. G. Rossman 2006), are shown in Fig. 6. It should be noted that the spectra were obtained by focusing the laser beam on the diasporic matrix away from microscopically detectable metallic minerals including anatase grains. The diaspore bands are observed in the low-wavenumber region, namely between $200 \mathrm{~cm}^{-1}$ and $600 \mathrm{~cm}^{-1}$. The most prominent are the $705 \mathrm{~cm}^{-1}, 446 \mathrm{~cm}^{-1}$ 
Table 1 - Summary of the XRD mineralogical analyses

\begin{tabular}{|c|c|c|c|}
\hline & Sample & Description & Major Minerals \\
\hline \multirow{12}{*}{ 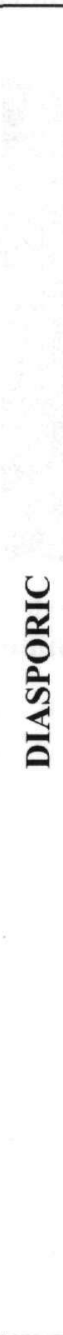 } & $\begin{array}{l}\text { ALM0306_PL1_B1 } \\
\left(3^{\text {rd }} \text { horizon }\right)\end{array}$ & $\begin{array}{l}\text { Red-brown to pale-brown, } \\
\text { Massive }\end{array}$ & Diaspore, Hematite, Kaolinite \\
\hline & $\begin{array}{l}\text { ALM0306_PL1_B3 } \\
\left(3^{\text {rd }} \text { horizon }\right)\end{array}$ & Red-brown, massive & Diaspore, Hematite, Anatase \\
\hline & $\begin{array}{l}\text { ALM0306_PL1_B4 } \\
\left(3^{\text {rd }} \text { horizon }\right)\end{array}$ & Red-brown, slightly porous & $\begin{array}{l}\text { Diaspore, Hematite, Goethite, } \\
\text { Kaolinite }\end{array}$ \\
\hline & $\begin{array}{l}\text { ELM0206_DV_B1 } \\
\left(2^{\text {nd }} \text { horizon }\right)\end{array}$ & Red-brown, massive & $\begin{array}{l}\text { Diaspore, Anatase, Magnetite, } \\
\text { Maghemite, Kaolinite }\end{array}$ \\
\hline & $\begin{array}{l}\text { SAB0306_ASV } \\
\left(3^{\text {rd }} \text { horizon }\right)\end{array}$ & Red-brown, massive & Diaspore, Hematite, Anatase \\
\hline & $\begin{array}{l}\text { ALM0306_PL1_BS2 } \\
\left(3^{\text {rd }} \text { horizon }\right)\end{array}$ & $\begin{array}{l}\text { White-grey-yellow, } \\
\text { highly porous }\end{array}$ & Diaspore, Anatase \\
\hline & $\begin{array}{l}\text { ALM0306_PL1_WB } \\
\left(3^{\text {rd }} \text { horizon }\right)\end{array}$ & $\begin{array}{l}\text { White-grey to pale-pink, } \\
\text { highly porous }\end{array}$ & Diaspore, Anatase \\
\hline & $\begin{array}{l}\text { ELM0206_SK_B1a } \\
\left(3^{\text {rd }} \text { horizon }\right)\end{array}$ & White-grey, highly porous & Diaspore, Anatase \\
\hline & $\begin{array}{l}\text { ELM0206_SK_B1b } \\
\left(3^{\text {rd }} \text { horizon }\right)\end{array}$ & $\begin{array}{l}\text { White-grey-yellow, } \\
\text { highly porous }\end{array}$ & Diaspore, Anatase \\
\hline & $\begin{array}{l}\text { ALM0306_PL1_BIW } \\
\left(3^{\text {rd }} \text { horizon }\right)\end{array}$ & White-grey, porous & Diaspore, Anatase \\
\hline & $\begin{array}{l}\text { ALM0306_BIW } \\
\left(3^{\text {rd }} \text { horizon }\right)\end{array}$ & $\begin{array}{l}\text { White-grey to pale-brown, } \\
\text { highly porous }\end{array}$ & Diaspore, Anatase \\
\hline & $\begin{array}{l}\text { ELM0206_SK_B2 } \\
\left(3^{\text {rd }} \text { horizon }\right)\end{array}$ & $\begin{array}{l}\text { White-grey to yellow- } \\
\text { brown, } \\
\text { highly porous }\end{array}$ & Diaspore, Anatase, Goethite \\
\hline \multirow{4}{*}{ 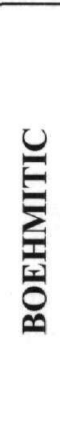 } & $\begin{array}{l}\text { ALM0306_PL1_B2 } \\
\left(3^{\text {rd }} \text { horizon }\right)\end{array}$ & Red-brown, massive & Boehmite, Hematite, Anatase \\
\hline & $\begin{array}{l}\text { ELM0206_KV_B1 } \\
\left(2^{\text {nd }} \text { horizon }\right)\end{array}$ & Red-brown, massive & Boehmite, Hematite, Kaolinite \\
\hline & $\begin{array}{l}\text { ELM0206_2H1 } \\
\left.\text { ( } 2^{\text {nd }} \text { horizon }\right)\end{array}$ & Red-brown-orange, massive & Boehmite, Goethite, Kaolinite \\
\hline & $\begin{array}{l}\text { SAB0306_SKR } \\
\text { ( } 2^{\text {nd }} \text { horizon) }\end{array}$ & Red-brown, massive & Boehmite, Hematite \\
\hline
\end{tabular}

and $260 \mathrm{~cm}^{-1}$, which are assigned to symmetric stretching modes (Ruan et al. 2001). In the porous white-grey bauxite samples the main diaspore band appears at $448 \mathrm{~cm}^{-1}$ (solid arrow in Fig. 5), which is assigned to Al-O-Al stretching bend, and it is in good agreement with the results from the literature (Ruan et al. 2001, see Fig. 6). A number of strong peaks are also observed in the band 
range between 1000 and $2000 \mathrm{~cm}^{-1}$ which are attributed to fluorescence from the $633 \mathrm{~nm} \mathrm{He}-\mathrm{Ne}$ laser. Fluorescence peaks are wavelength-dependent and they should disappear when another laser is used, such as a Nd:YAG laser at $1064 \mathrm{~nm}$. In synthetic diaspore a number of broad bands are observed with the $1064 \mathrm{~nm}$ laser in the $2800-3700 \mathrm{~cm}^{-1}$ region, attributed to the $v(\mathrm{OH})$ stretching. These bands were not observed in our spectra. The massive red-brown samples along with diaspore contain hematite (empty arrows in Fig. 5) with Raman bands at $612 \mathrm{~cm}^{-1}, 496 \mathrm{~cm}^{-1}, 412$ $\mathrm{cm}^{-1}, 293 \mathrm{~cm}^{-1}$ and $225 \mathrm{~cm}^{-1}$ (Faria et al. 1997, Bersani et al. 1999, Chamritski and Burns 2005, Zoppi et al. 2005, Zoppi et al. 2006).

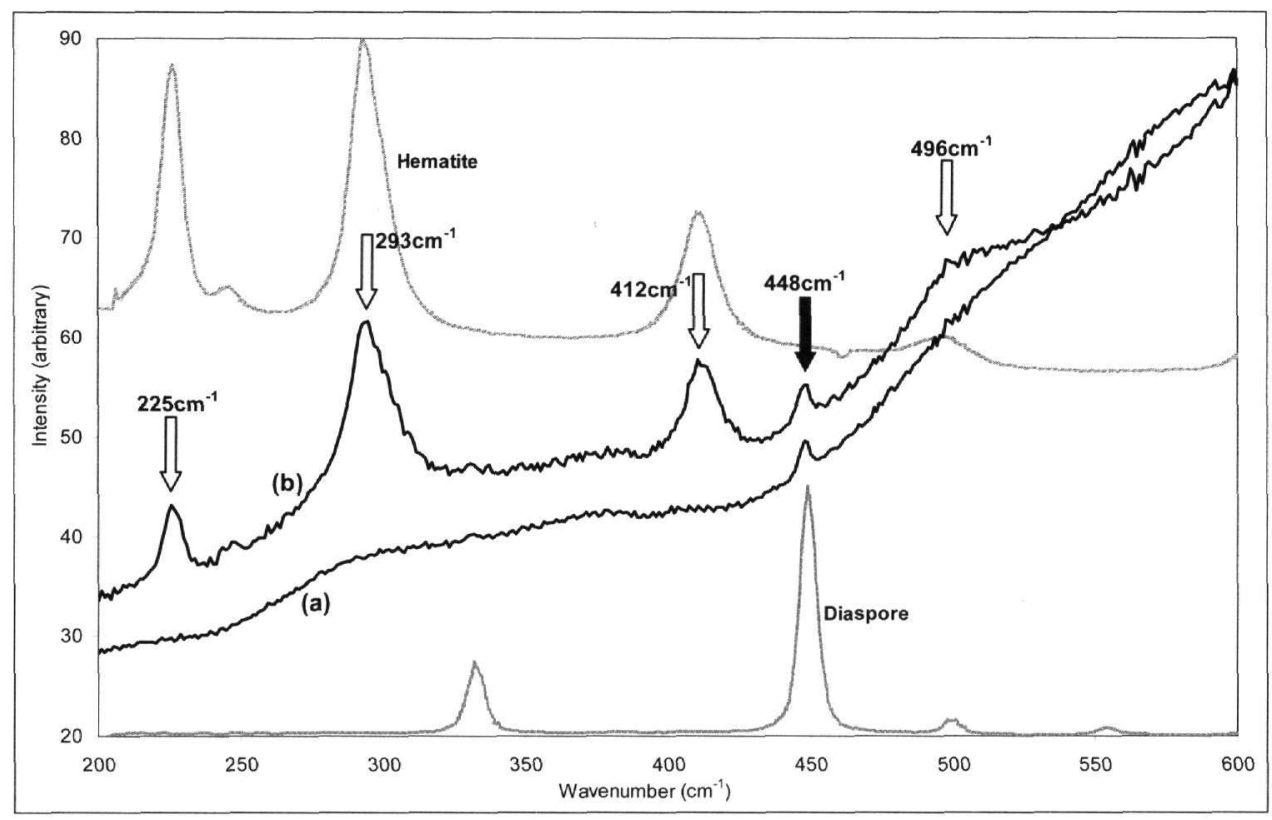

Figure 5 - Representative Laser $\mu$-Raman spectra of diasporic bauxite samples in the lowwavenumber region (a: porous white-grey and b: massive red-brown). The lower spectrum corresponds to the Mineral Spectroscopy Server diaspore and the upper to standard hematite

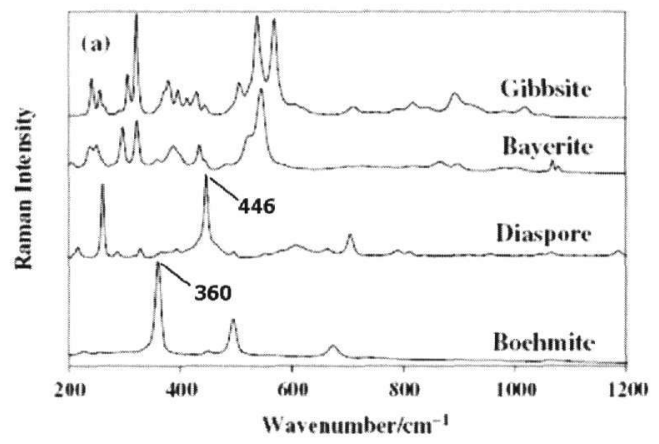

Figure 6 - Raman spectra of different AIOOH polymorphs (Ruan et al. 2001). It is clearly marked the difference of the diasporic Raman band at $446 \mathrm{~cm}^{-1}$ from the one of the boehmite at $360 \mathrm{~cm}^{-1}$, at the low-wavenumber region between $250 \mathrm{~cm}^{-1}$ and $600 \mathrm{~cm}^{-1}$

Representative Laser $\mu$-Raman spectra of boehmitic bauxite samples (massive red-brown) are shown in Figure 7 (low-energy region). According to literature, the more intense boehmite peaks at the low-wavenumber region are at $674 \mathrm{~cm}^{-1}, 495 \mathrm{~cm}^{-1}$ and $360 \mathrm{~cm}^{-1}$ and they correspond to the 
hydroxyl translational modes. In our samples we observe the $362 \mathrm{~cm}^{-1}$ band (Ruan et al. 2001, see Fig. 6). The spectrum (a) from Figure 7 corresponds to the boehmitic matrix of the sample, at an area where metallic minerals, such as rounded hematite aggregates were not optically visible. This band (solid arrow in Fig. 7) is observed between the $412 \mathrm{~cm}^{-1}$ and $293 \mathrm{~cm}^{-1}$ hematite bands and it could be used as a rule of thumb to easily distinguish it from the diasporic peak which is observed outside these hematite peaks (Faria et al. 1997, Bersani et al. 1999, Chamritski and Burns 2005, Zoppi et al. 2005, Zoppi et al. 2006).

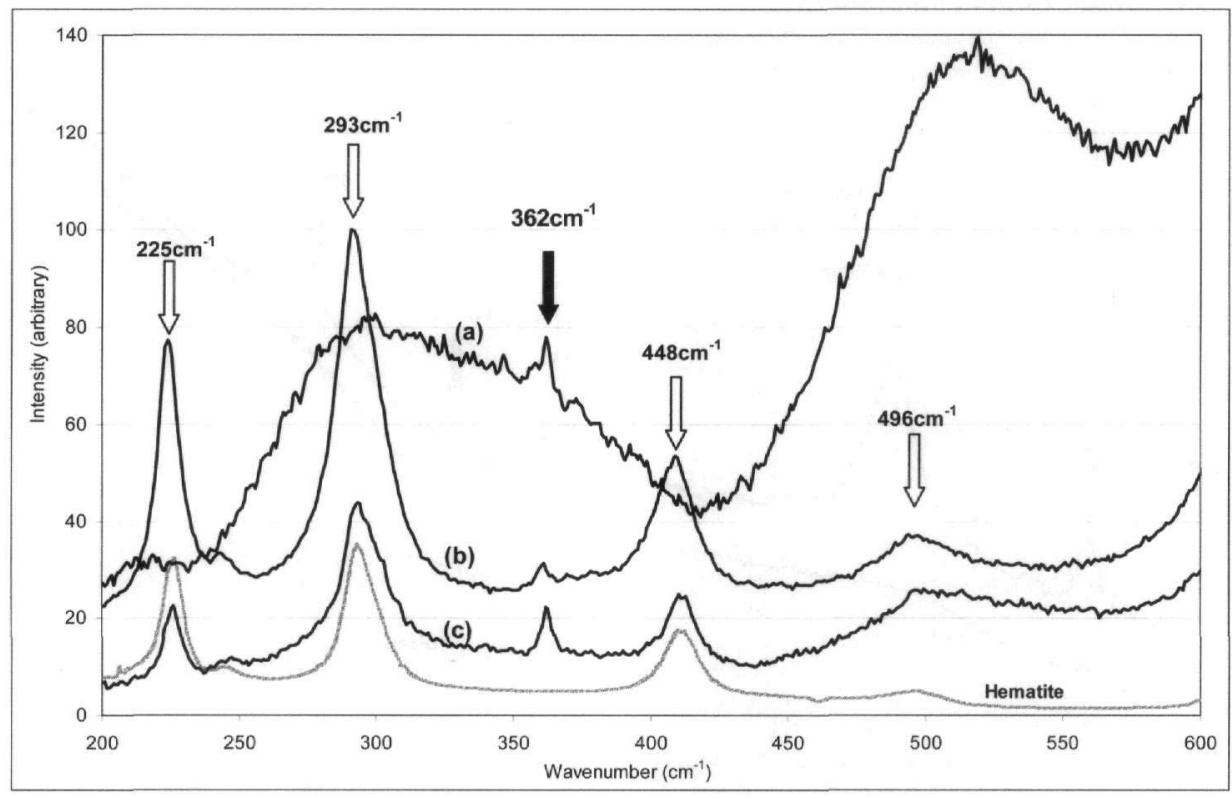

Figure 7 - Representative Laser $\mu$-Raman spectra of boehmitic bauxite samples in the lowwavenumber region (a, b, c: massive red-brown). The lower spectrum corresponds to the Mineral Spectroscopy Server hematite

At this point one could refer that the hematite Raman bands differ evidently to that of goethite, which may also be present in massive red-brown bauxites (either diasporic or boehmitic). In this case, the AlOOH polymorph bands (either at $448 \mathrm{~cm}^{-1}$ or $362 \mathrm{~cm}^{-1}$ ) are most probably expected to be distinguishable at the opposite sides of the main goethite band around $385 \mathrm{~cm}^{-1}$ (Faria et al. 1997, Bersani et al. 1999). Furthermore, it also expected that diaspore and boehmite lowwavenumber Raman bands will be apparent if kaolinite is present, under the laser beam spot, inasmuch the main -very intense- kaolinite band appears at $140 \mathrm{~cm}^{-1}$ (Johnston et al. 1984, Frost et al. 1993).

Table 2 - Summary of the Laser $\mu$-Raman data

\begin{tabular}{|c|c|c|}
\hline & \multicolumn{2}{|c|}{ Raman bands $\left(\mathrm{cm}^{-1}\right)$} \\
\hline & $\begin{array}{c}\text { AlOOH } \\
\text { polymorphs }\end{array}$ & $\begin{array}{l}\text { Hematite } \\
\left(\alpha-\mathrm{Fe}_{2} \mathrm{O}_{3}\right)\end{array}$ \\
\hline \multicolumn{3}{|l|}{ Diasporic Type } \\
\hline White-grey bauxites & 448 & - \\
\hline Red-brown bauxites & 448 & $412,293,225$ \\
\hline \multicolumn{3}{|l|}{ Boehmitic Type } \\
\hline Red-brown bauxites & 362 & $612,412,293,225$ \\
\hline
\end{tabular}


Concluding, the results of the present study suggest that Laser $\mu$-Raman spectroscopy could be applied for the fast determination of the $\mathrm{AlOOH}$ polymorphs and, as a consequence, the "type" of bauxite of the Parnassos-Ghiona active mining area (central Greece). In the case of the white-grey (high-quality) diasporic bauxite there is a clear diaspore Raman band at $448 \mathrm{~cm}^{-1}$ to be used as the characteristic band, while in the case of the typical red-brown diasporic bauxite the same band is accompanied by the unavoidable bands of hematite (Table 2). For the red-brown boehmitic bauxite, the main Raman band of boehmite appears at $362 \mathrm{~cm}^{-1}$, between two major hematite bands. It is therefore demonstrated that both diasporic and boehmitic bauxites can easily be characterized by recording Raman spectra in the $250 \mathrm{~cm}^{-1}-600 \mathrm{~cm}^{-1}$ region. In this lowwavenumber region the bands of the $\mathrm{AlOOH}$ polymorphs do not interfere with bands from other bauxite minerals. A portable Raman system with a CCD acquisition camera and with a laser operating at the wavelength of $1064 \mathrm{~nm}$ could be used to rapidly acquire the narrow spectra range between $250 \mathrm{~cm}^{-1}$ and $600 \mathrm{~cm}^{-1}$. The He-Ne laser with a wavelength of $633 \mathrm{~nm}$ introduces significant fluorescence which might suppress the Raman peaks and make them invisible. However, it still can be used when the CCD is centred to cover the low wavenumber region but it may require longer integration times. The use of a powder XRD or of another time-consuming technique is not necessary in order to distinguish the type of bauxite (diasporic or boehmitic). This could be particularly useful in characterising similar in appearance samples such as the massive red-brown samples (e.g. SAB0306_ASV and SAB0306_SKR, see Table 1) which could be of diasporic or boehmitic type. Future work could employ direct tests on site with a portable Raman system that has the above characteristics. Furthermore, one could proceed into calibrating a portable system to acquire quantitative or semi-quantitative information for precise quality assessment during production.

\section{Acknowledgments}

We would like to thank the Greek bauxite mining companies (Aluminium de Grèce S.A., S\&B Industrial Minerals S.A. and Elmin S.A.) for their kindly help concerning underground visits and supply of samples from their Parnassos-Ghiona mines.

\section{References}

Aronis, G. A., 1955. Geographical distribution, geological placing and aspects on the genesis of the Greek bauxites, Bull. Geol. Soc. Greece, 2, 55-79.

Arp, T., 1985. Geologische Kartierung des Gebietes um Tithronion im Kallidromongebirge, Mittelgriechenland und petrographische Bearbeitung des Karstbauxites (b1), PhD Thesis, Univ. of Hamburg, Hamburg, 213pp. (unpublished)

Augustithis, S.S., Mack, E., and Vgenopoulos, A., 1978. Textural and geochemical comparisons of the oolitic and pisolitic structures of the Parnassus Bauxites and the Ni-Cr-Fe Laterites of Larymna/Lokris and Euboea, Greece, 4th International Congress for the Study of Bauxites, Alumina and Aluminum, Athens. October 9-12, 15-34pp.

Bárdossy, Gy., 1982. Karst Bauxites. Bauxite Deposits on Carbonate Rocks, Elsevier, 441 pp.

Bárdossy, Gy., and Mack, E., 1967. Zur Kenntnis der Bauxite des Parnass-Kiona-Gebirges, Mineralium Deposita, 2, 334-348.

Bárdossy, Gy., and Pantó, Gy., 1971. Investigation of Bauxites with Help of Electron-Probe, TMPM Tschermarks Min. Petr. Mitt., 15, 165-184.

Bersani, D., Lottici, P.P., and Montenero, A., 1999. Micro-Raman Investigation of Iron Oxides Films and Powders Produced by Sol-Gel Syntheses, J. Raman Spectrosc., 30, 355-360. 
Biermann, M., 1983. Zur Mineralogie, Geochemie und Genese des Karstbauxites (B3-Horizont) an der Grenze Unter- Oberkreide in Mittelgriechenland, PhD Thesis, Univ. of Hamburg, Hamburg, 134 pp.

Chamritski, I., and Burns, G., 2005. Infrared and Raman-Active Phonons of Magnetite, Maghemite and Hematite: A Computer Simulation and Spectroscopic Study, J. Phys. Chem., 109, 4965-4968.

Combes, P.J., 1979. Observations sédimentologiques, paléogéographiques, minéralogiques et géochimiques sur les bauxites du deuxiéme horizon dans la zone du Parnasse (Gréce), Bull. Soc. Géol. Fr., (7), XXI, 4, 485-494.

Combes, P.J., and Andreou, G., 1983. Utilisation de la paléogéographie pour la prospection de bauxite dans une région de nappe: un example au nord de Distomon (zone du Parnasse, Gréce), 5th Int. Congress ICSOBA, Zagreb, 223-231.

Combes, P.J., Fourcade, E., Masse, J.P., and Philip, J., 1981. Observations stratigraphiques et paléontologiques sur la Crétacé de la zone du Parnasse, Trav. Comité Int. Etude des Bauxites, de l'Alumine et de Aluminium, Acad. Yougoslav. Sci. Arts, 11 (16), 347-365.

Economopoulos, I.E., and Vgenopoulos, A.G., 1998. An approach concerning bauxites, bauxitization and mining in Greece, Mineral Wealth, 109, 21-34. (in English, with Greek abstract)

Economopoulou-Kyriakopoulou, N., 1991. A comparative geochemical and mineralogical study of bauxitic horizons in central Greece, PhD Thesis, National Technical University of Athens, Faculty of Mining Engineering and Metallurgy. Athens, 119pp. (unpublished)

Faria, D.L.A., Venâncio Silva, S., and Oliveira, M.T., 1997. Raman Microspectroscopy of Some Iron Oxides and Oxyhydroxides, J Raman Spectrosc., 28, 873-878.

Frost, R.L., Fredericks, P.M., and Bartlett, J.R., 1993. Fourier transform Raman spectroscopy of kandite clays, Spectrochimica Acta, 49A (5/6), 667-674.

Johnston, C.T., Sposito, G., Bocian, D.F., and Birge, R.R., 1984. Vibrational spectroscopic study of the interlamellar kaolinite-dimethyl sulfoxide complex, Journal of Physical Chemistry, $88,5959-5964$.

Kiskyras, D., 1960. Die mineralogische Zusammensetzung der griechischen Bauxite in Abhängigkeit von der Tektonik, Neues Jahrb. Mineral. Abhandl., 94, 662-680.

Kritsotakis, K., Schulz-Dobrick, B., and Panagos, A.G., 1986. REE-Minerale in Griechischen Bauxiten, Fortschritte der Mineralogie, Beiheft, 64 (1), 87.

Laskou, M., 1991. Concentrations of rare earths in Greek Bauxites, Acta Geologica Hungarica, 34 (4), 395-404.

Laskou, M., 2001. Chromite in karst bauxites, bauxitic laterites and bauxitic clays of Greece. In Piestrzynski, et al. (eds), Mineral Deposits at the Beginning of the 21st century, 6th Biennial SGA Meeting, Krakow. Millpress, Rotterdam, 1091-1094pp.

Laskou, M., 2005. Pyrite-rich bauxites from the Parnassos-Ghiona zone, Greece. In Mao, et al. (eds), 8th SGA Meeting, "Mineral Deposits Research Meeting the Global Challenge" Beijing, August 18-21, 1007-1010pp.

Laskou, M., and Andreou, G., 2003. Rare earth element distribution and REE-minerals from the Parnassos-Ghiona bauxite deposits, Greece. In D. Eliopoulos, et al. (eds), Mineral Exploration and Sustainable Development, 7th Biennial SGA Meeting, Athens. Millpress, Rotterdam, 89-92pp. 
Laskou, M., and Economou, M., 1991. Platinum group elements and gold concentrations in Greek bauxites, Geologica Balcanica, 21 (2), 65-77.

Laskou, M., and Economou, M., 2006. The role of microorganisms on the mineralogical and geochemical characteristics of the Parnassos-Ghiona bauxite deposits, Greece, Journal of Geochemical Exploration. (in press)

Lymperopoulou, Th., 1996. Determination and extraction of rare earth elements from bauxites and red mud, PhD Thesis, National Technical University of Athens, Faculty of Chemical Engineering, Athens, 183pp. (unpublished)

Mack, E., and Petrascheck, W.E., 1978. Palaeogeographie, Verteilung und Qualität der Bauxite im Parnass-Kjona Gebirge, 4. Intern. Congr. ICSOBA, 2, 526-539.

Maksimović, Z., and Papastamatiou, J., 1973. Distribution d'oligoélements dans les gisements de bauxite de la Grèce centrale, Symp. ICSOBA, Nice, 33-46.

Nia, R., 1968. Geologische und petrographische Untersuchungen zum Problem der BoehmitDiaspor-Genese in griechischen Oberkreide-Bauxiten der Parnass-Kiona-Zone, PhD Thesis, Univ. of Hamburg, Hamburg, 133pp.

Nia, R., 1968. Zur Bedeutung der methodischen Probennahme für genetische Untersuchungen von Bauxit-Lagerstätten am Beispiel der Oberkreide-Bauxite der Parnass-Kiona-Zone Griechenlands, Mineralium Deposita, 3, 368-374.

Nia, R., 1971. Genesis of boehmite and diaspore in Greek Upper Cretaceous bauxites of the Parnasse-Gjona zone, Proc. $2^{\text {nd }}$ Int. Syrup. ICSOBA, Budapest, 69-98.

Nicolas, J., and Bildgen, P., 1979. Relations between the location of the karst bauxites in the northern hemisphere, the global tectonics and the climatic variations during geological time, Palaeogeography, Palaeoclimatology, Palaeoecology, 28, 205-239.

Ochsenkühn, K.M., Fafouteli, P., and Ochsenkühn-Petropoulou, M., 2002. Determination and distribution of gold in Greek Bauxites of the Parnassos-Gkiona area by gammaspectroscopy after ion exchange separation, Journal of Radioanalytical and Nuclear Chemistry, 253(2), 257-262.

Ochsenkühn, K.M., Ochsenkühn-Petropoulu, M., and Parissakis, G., 1995. Activation analysis of bauxitic materials by epithermal irradiation, Journal of Radioanalytical and Nuclear Chemistry, 190 (1), 75-79.

Ochsenkühn, K.M., and Parissakis, G., 1977. Quantitative Untersuchungen von Bauxiten Zentralgriechenlands mittels Atomabosrptions-spectroscopie und Flemmenatomemission, Microchimica Acta, 1, 447-457.

Ochsenkühn-Petropoulou, M., and Ochsenkühn, K.M., 1995. Comparison of inductively coupled plasma mass spectrometry with inductively coupled plasma atomic emission spectrometry and instrumental neutron activation analysis for the determination of rare earth elements in Greek bauxites, Spectrochimica Acta, 46 (1), 51-65.

Ochsenkühn-Petropoulou, M., and Ochsenkühn, K.M., 1995. Rare earth minerals found in Greek Bauxites by SEM and EPMA, European microscopy and analysis, September 1995, 13-14.

Papastamatiou, J., 1960. La géologie de la région montagneuse du Parnass-Kiona-Oeta, Bull. Géol. Soc. Fr. 7, 398-409.

Papastamatiou, J., 1964. Les gisements de bauxite en Gréce, 1st Symp. ICSOBA, Zagreb, 285-293. 
Papastavrou, S., 1974. Einige Bemerkungen zur Relation zwischen Verkarstungsbahnen und Längserstreckung der Bauxitlager bei Sideroporto-Bela, Ann. Fac. Phys. - Math, Univ., 199.

Papastavrou, S., 1986. Greek bauxites (Description - Classification - Distribution - Problems), Mineral Deposits Research. IGME, Internal Report. Athens, 30pp. (in Greek, with English abstract)

Papastavrou, S., and Perdikatsis, V., 1987. U-Th and REE concentrations in bauxites and new aspects about the origin of bauxites in the mountains, Mineral Deposits of the Tethyan Eurasian Belt, ed. S. Janković, Faculty of Mining, Belgrade.

Paspaliaris, J., 1985. A contribution to the optimization of diasporic bauxite leaching process, $P h D$ Thesis, National Technical University of Athens, Faculty of Mining Engineering and Metallurgy, Athens, 185pp. (unpublished)

Perdikatsis, V., 1992. Quantitative mineralogical analysis of bauxites by X-ray diffraction with the Rietveld method, Acta Geologica Hungarica, 35 (4), 447-457.

Petrascheck, W.E., 1989. The genesis of allochthonous karst-type bauxite deposits of southern Europe, Mineralium Deposita, 24, 77-81.

Ruan, H.D., Frost, R.L., and Kloprogge, J.T., 2001. Comparison of Raman spectra in characterizing gibbsite, bayerite, diaspore and boehmite, J. Raman Spectrosc., 32, 745-750.

Solymár, K., Mádai, F., and Papanastasiou, D., 2005. Effect of bauxite microstructure on beneficiation and processing, Light Metals 2005 Edited by Halvor Kvande TMS (The Minerals, Metals \& Materials Society), 47-52pp.

Valeton, I., 1972. Bauxites. Development in Soil Sciences, 1, Elsevier, 226pp.

Valeton, I., 1991. Processes of allochthony and autochthony in bauxites on carbonate platforms of the Mediterranean Area, Mineral Wealth, 71, 13-28.

Valeton, I., Biermann, M., Reche, R., and Rosenberg, F., 1987. Genesis of nickel laterites and bauxites in Greece during the Jurassic and the Cretaceous and their relation to ultrabasic rocks, Ore Geology Reviews, 2, 359-404.

Vgenopoulos, A., and Daskalakis, K., 1991. Remarks on the genesis and ore-dressing of the alluvial bauxite occurrences of Parnassos-Gkiona-Elikon, Acta Geologica Hungarica, 34 (4), 405-407.

Zoppi, A., Lofrumento, C., Castellucci, E.M., Dejoie, C., and Sciau, Ph., 2006. Micro-Raman study of aluminium-bearing hematite from slip of Gaul sigillata wares, J. Raman Spectrosc., 37, 1131-1138.

Zoppi, A., Lofrumento, C., Castellucci, E.M., and Migliorini, M.G., 2005. The Raman spectrum of hematite: Possible indicator for a compositional or firing distinction among terra siggillata wares, Annali di Chimica, 95, 239-246. 